\title{
River therapy
}

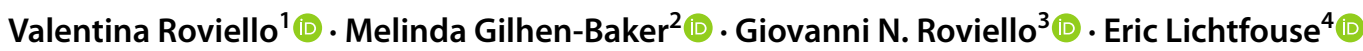

Published online: 17 January 2022

(c) The Author(s), under exclusive licence to Springer Nature Switzerland AG 2021

The successive lockdowns of the coronavirus 2019 pandemic have substantially increased citizens will to escape from the city and seek out nature for walking, cycling, swimming and other health-enhancing activities. While the heatlh benefits of bathing in natural rivers is empirically known since ancient times, wild swimming is actually booming as never before, partly in response to the lockdowns imposed by the coronavirus 2019 (COVID-19) pandemic. In the United Kingdom, the vogue for taking a cold plunge can be traced back to 1587 when a Cambridge don suggested using pigs' bladders for water wings (Macintyre 2021). In France, king Henry IV (1553-1610), also known as the Green Gallant, enjoyed cold bathing in Paris, which marks the start of wild swimming in the Seine river by a rising population after 1600 (Duhau 2007). Humans benefit enormously from the positive effects of clean rivers on human health. Good quality river waters together with good biodiversity and a riparian habitat structure all concur to create such a positive practice. There is quantitative evidence for the relaxing effect of the sounds made by rivers. Moreover, riparian vegetation can boost human immunity after inhalation

Giovanni N. Roviello

giroviel@unina.it

Valentina Roviello

valentina.roviello@unina.it

Melinda Gilhen-Baker

mgbaker@me.com

Eric Lichtfouse

eric.lichtfouse@gmail.com

1 Department of Chemical, Materials and Industrial Production Engineering (DICMaPI), University of Naples Federico II, Piazzale V. Tecchio 80, 80125 Naples, Italy

2 Faculty of Physical Medicine and Rehabilitation, Georgian State Teaching University of Physical Education and Sport, 49, Chavchavadze avenue, 0162 Tbilisi, Georgia

3 IBB-CNR Mezzocannone Site and Headquarters, Istituto Di Biostrutture E Bioimmagini, 80145 Naples, Italy

4 Aix-Marseille Univ, CNRS, IRD, INRA, CEREGE, 13100 Aix-en-Provence, France of plant-emitted volatile organic compounds. River waters carry plant metabolites that are known ingredients of traditional medicines which induce, among other beneficial effects, antipsoriatic healing. Protecting river ecosystems and improving water quality are therefore challenges worth facing to improve psychological and physical wellness. Here, we present scientific insights on river therapy, aimed at healing both psychological stress and physical disease.

\section{Declining river health}

Since early human history, rivers have been an essential source of food and water, as well as a natural waterway for transport. Rivers are a central feature of the planet ecology, constituting a vital ecosystem for many species (Sadoff and Grey 2002). Moreover, cultural and recreational uses of fluvial ecosystems such as walking, bathing, fishing and camping are now popular passtimes (Doi et al. 2013; Kistemann et al. 2016). Such leisurely uses are only possible with good aquatic health, which can be monitored by the abundance and diversity of fish and other pollution-sensitive species (Roviello and Roviello 2019). Indeed, there is a decline in the recreational use of rivers when biodiversity and river health decrease (Doi et al. 2013). Unfortunately, many river ecosystems are actually highly degraded by urbanization, industrialization and pollution (Heim et al. 2003; Terasaki et al. 2012; Wu et al. 2018). In urban areas, pollution includes:

- eutrophication and faecal water contamination (Gecheva and Yurukova 2013; Dsikowitzky et al. 2017),

- migration of pollutants from heating plants to river sediments (Samelak et al. 2019),

- water microplastic contamination (Wang et al. 2019),

- herbicide water contamination (Barek et al. 2009), and

- river sediment pollution by polycyclic aromatic hydrocarbons (Barra et al. 2008). 
Environmental pollution caused by algal and bacteria blooms alters the recreational use of rivers by diminishing water transparency and, in turn, conveying a negative visual perception to inhabitants (Doi et al. 2013). Air pollution by photochemical smog in the vicinity of highly polluted rivers also degrades the health of human populations living along the riverside (Juang et al. 2008; Feng et al. 2018).

\section{River therapy}

Populations who walk or live in natural forests or riparian woodlands breathe beneficial volatile substances emitted by plants. Such forest bathing induces positive effects on the human immune system and has inspired the design of green medical prescriptions (Roviello and Roviello 2021b, 2021a; Roviello et al. 2021; Robinson and Breed 2019). Here, we present the benefits provided by pristine rivers on human health from psychological and therapeutic perspectives (Fig. 1). Relaxing river sounds, biogenic volatile organic compounds emitted by riparian vegetation and secondary plant metabolites found in river waters all concur to improve human psychological and physical wellness. This suggests the novel concept of river therapy, and highlights the need for clean river preservation and pollution remediation in the case of highly contaminated rivers, especially in densely populated urban areas.

\section{Beneficial plant chemicals}

We analyzed the literature for phytochemicals of biomedical potential that are released into rivers from riparian vegetation or emitted from riverine plants as volatile compounds, potentially inhalable by humans. Remarkably, many secondary plant metabolites, chemically heteroaromatic compounds, especially flavonoids and their glycosilated forms, occur in river waters (Fig. 2, up) at concentrations up to about $5 \mu \mathrm{g} / \mathrm{L}$ (Nanusha et al. 2020). These metabolites are produced in large amounts depending on the plant species, climate and environmental conditions. They control essential plant functions such as growth and reproduction, and they establish ecological and biological relationships with other living organisms (Nanusha et al. 2020). The most abundant metabolites are apiin from Apiaceae and Urtica dioica, hyperoside from Hypericum species, Fraxinus excelsior and Galanthus nivalis, and guanosine from Digitalis purpurea.

Living near polluted rivers increases diseases, e.g. by inhalation of anthropogenic volatile organic compounds such as 1,2-dibromo-3-chloropropane, hexachlorobutadiene and 1,2-dibromoetane (Juang et al. 2008). By contrast, well preserved riparian ecosystems offer residents health benefits by releasing beneficial plant-emitted compounds which are

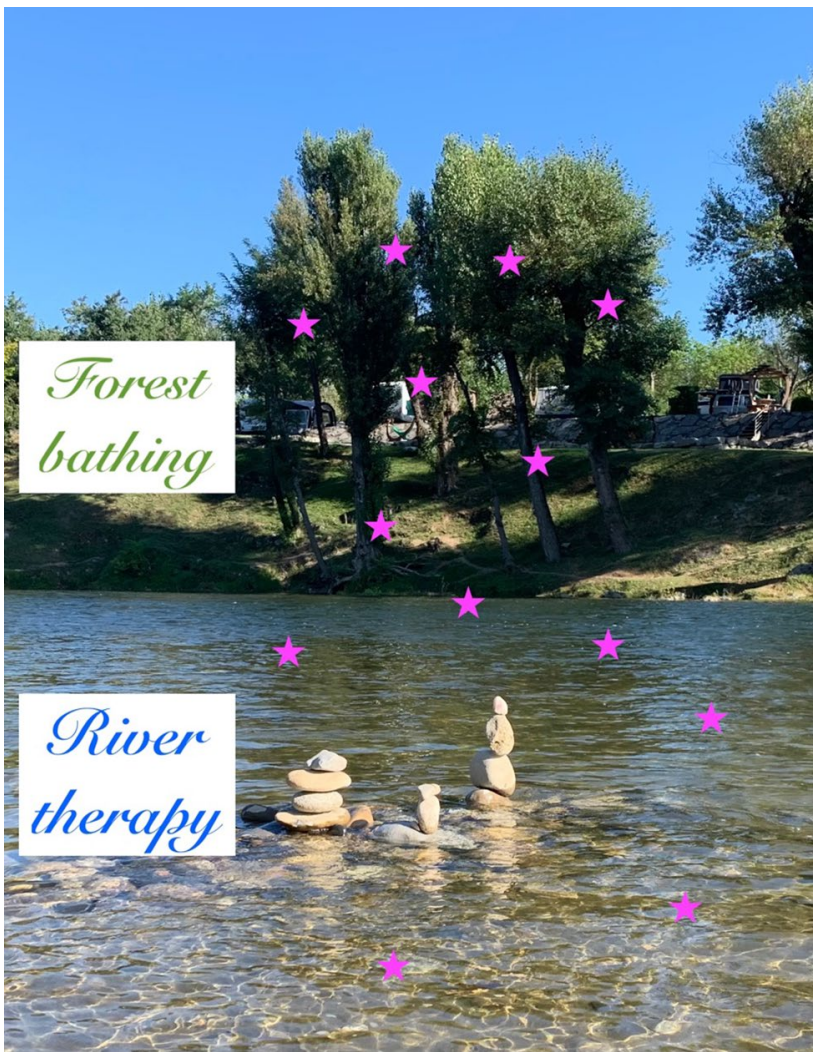

Fig. 1 Forest bathing refers to walking in forests to benefit from naturally healing cures such as breathing immunity-enhancing substances emitted by plants, e.g. limonene. River therapy refers to walking near or swimming in a river to benefit from naturally healing cures such as water-soluble plant metabolites, e.g. apiin, and relaxing river sound. Photo: copyright Eric Lichtfouse 2021, Ardèche river

inhaled. For instance, limonene, 3 -carene and $\beta$-myrcene were identified in the air near riparian shrubs (Khalaj et al. 2021).

\section{Healing psoriasis with plant metabolites}

Psoriasis is a chronically recurrent autoimmune inflammatory skin disease in which keratinocyte hyperplasia is accompanied by inflammatory cell infiltration into the dermis and neovascularization, and affects more than $2 \%$ of the global population (Wei et al. 2016). The main psoriasis proteins studied, NF- $\mathrm{\kappa B}$, IL-17, and IL-3 can be targeted by several plant-derived products including diterpenoids, triterpenoids and hydroxycinnamic acids (Lo et al. 2019). Interestingly, we found that some secondary plant metabolites such as isofraxidin which has been detected in river waters (Fig. 2), are also ingredients of an effective antipsoriatic herbal drug that inhibits keratinocyte proliferation by downregulating cyclin B2 (Wei et al. 2016). 
Water soluble Plant Metabolites in Rivers<smiles>O=c1c(O)c(-c2ccc(O)cc2)oc2cc(O)cc(O)c12</smiles>

Kaempferol<smiles>C[C@H]1O[C@H](OC[C@H]2O[C@H](Oc3c(-c4ccc(O)cc4)oc4cc(O)cc(O)c4c3=O)[C@H](O)[C@@H](O)[C@H]2O)[C@H](O)[C@@H](O)[C@H]1O</smiles><smiles>COc1cc2ccc(=O)oc2c(OC)c1O</smiles>

Isof raxidin<smiles>Nc1ncnc2nc[nH]c12</smiles>

Adenine<smiles>O=c1c(O)c(-c2ccc(O)c(O)c2)oc2cc(O)cc(O)c12</smiles>

Quercetin<smiles>O=c1cc(-c2ccc(O)c(O)c2)oc2cc(O[C@@H]3O[C@H](CO)[C@@H](O)[C@H](O)[C@H]3O)cc(O)c12</smiles>

Cynaroside<smiles>COc1cc(O)cc2c1C(=O)C[C@@H](c1ccccc1)O2</smiles>

Alpinetin<smiles>O=c1c(O[C@@H]2O[C@H](CO)[C@@H](O)[C@H](O)[C@H]2O)c(-c2ccc(O)c(O)c2)oc2cc(O)cc(O)c12</smiles>

Hyperoside<smiles>Nc1nc2c(ncn2[C@@H]2O[C@H](CO)[C@@H](O)[C@H]2O)c(=O)[nH]1</smiles>

Guanosine

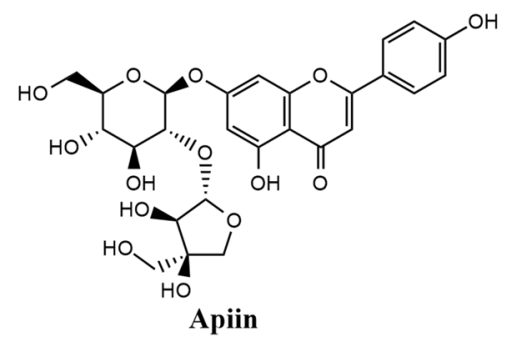<smiles>O=c1c(O[C@@H]2O[C@H](CO)[C@@H](O)[C@H](O)[C@H]2O)c(-c2ccc(O)cc2)oc2cc(O)cc(O)c12</smiles>

Trifolin<smiles>C[C@@H]1O[C@H](Oc2cc(O)c3c(=O)c(O[C@@H]4O[C@H](C)[C@@H](O)[C@H](O)[C@H]4O)c(-c4ccc(O)cc4)oc3c2)[C@H](O)[C@H](O)[C@@H]1O</smiles>

Kaempferitrin

Plant Volatile Organic Compounds from Riparian vegetation

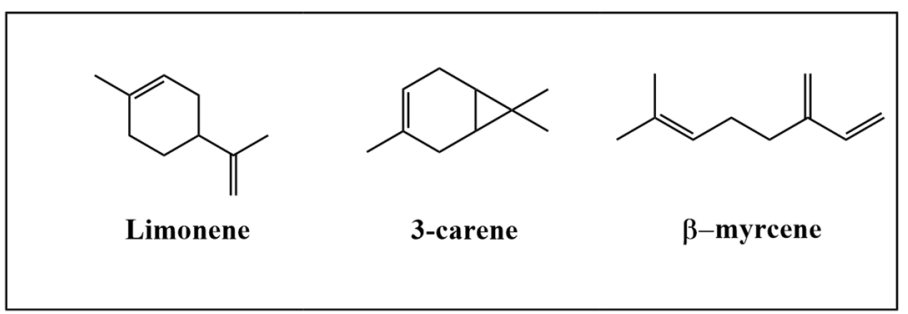<smiles>CC(C)=C1CC[C@H](C)C2=C(C1)[C@H](C)CC2</smiles>

$\beta$-guaiene<smiles>C=CC(C)=CCC=C(C)C</smiles>

$\beta$-ocimene
Fig. 2 Top: plant metabolites detected in river waters. In particular, hyperoside, guanosine and apiin are among the most abundant (upper box). Bottom: main biogenic volatile organic compounds emitted by riparian vegetation. The most abundant limonene, 3-carene and $\beta$-myrcene are shown in the lower box 
Many antipsoriatic treatments are applied locally on the skin surface as lotions, creams, shampoos and ointments (Torsekar and Gautam 2017). Therefore, we hypothesize that prolonged and repeated body exposure to secondary plant metabolites in river waters could treat psoriasis and may even limit the secondary effects of the classical administration (Zhang et al. 2019). The potential benefit of apiin as antipsoriatic is supported by the fact that apigenin, the product of acid hydrolysis of apiin, alleviates psoriasis by improving skin functions (Park et al. 2020). Similarly, quercetin, the hydrolysis product of hyperoside, exerts in vitro and in vivo anti-inflammatory effects, indicating that both flavonoids are promising antipsoriatic agents (Bonesi et al. 2018).

Cold river waters could relieve the pruritus in chronic plaque psoriasis. Indeed, under clinical conditions, low temperature water is effective in relieving the pruritus, while conventional anti-pruritic therapies have only limited effects (Stinco 2014). Moreover, river waters are used in India to treat chronic psoriasis. Here, a study using Ganga river waters reveals sustained benefits after four weeks of treatment, thus suggesting a therapeutic use of the river waters (Jhunjhunwala and Waghralkar 2021).

\section{Immunotherapy by inhaling volatile organic compounds from riparian vegetation}

Riparian shrubs emit various volatile compounds: monocyclic terpenes such as limonene and $\alpha$-phellandrene, bicyclic terpenes including, 3-carene, camphene, $\alpha$-pinene, $\beta$-guaiene, caryophyllene and sabinene, and acyclic terpenes such as $\beta$-myrcene and $\beta$-ocimene (Khalaj et al. 2021). Limonene accounts for more than $45 \%$ of the total amount of these biogenic volatile organic compounds, followed by 3 -carene, about $24 \%$, and $\beta$-myrcene, about $18 \%$. We suggest that these compounds from riparian vegetation have health benefits similar to forest bathing (Mao et al. 2012). Forest bathing consists of visiting green areas and walking under the tree canopy to experience health benefits, mainly on the body's immune system (Li 2009). Forest bathing induces positive effects that last several days after the trip and increases natural killers activity, which leads to effects on virus-infected cells. Furthermore, several volatile terpene compounds emitted by trees induce anti-inflammatory responses, thus reducing respiratory system inflammation. This may be of particular interest for the coronavirus 2019 pandemic (COVID-19)(Dai et al. 2021; Ufnalska and Lichtfouse 2021; He et al. 2021; Khan et al. 2021) caused by SARS-CoV-2, as discussed in the literature (Roviello et al. 2021; Roviello and Roviello 2021 a,b). Concerning riverside forest bathing, the main volatile organic compound emitted from riparian vegetation, i.e. limonene, is endowed with immunomodulatory properties (Jin et al. 2008).

3-Carene is known for its antimicrobial properties, showing particularly strong antibacterial effects on both Grampositive Brochothrix thermosphacta and Gram-negative Pseudomonas fluorescens bacteria. Indeed, 3-carene causes bacterial membrane damage, DNA disruption and metabolic perturbations, thus interfering in bacterial cellular functions (Shu et al. 2019). $\beta$-Myrcene, the third most abundant volatile organic compound from riparian vegetation is an antiparasitic drug. $\beta$-Myrcene was tested in vitro against germinal cells, protoscoleces and murine cysts of Echinococcus granulosus, and in vivo as chemoprophylactic agent in a murine model of cystic echinococcosis. Results showed that $\beta$-myrcene displays antiparasitic activities, similarly to albendazole, the standard drug for human echinococcosis (Fabbri et al. 2018).

\section{River sound therapy}

Relaxation techniques give relief from negative conditions including pain, stress, and anxiety. We searched the literature for the possible use of river sound in psychological therapy. We found that river sounds are used as a background in relaxation training systems based upon virtual reality neurofeedback, developed to help people relax faster and deeper (Gu and Frasson 2017). This relaxation training system induces a decrease of the anxiety and depression score, a decrease in the time interval to relaxation and increases the maximum meditation score. We also found that river sound accompanied by relaxation exercises diminished pregnancy-related anxiety in pregnant women with a history of perinatal loss (Duman et al. 2020). Watching a river also relieves psychological stress. For instance, during the restoration phase at work in open-space offices, workers who saw a video footage of a river including sound, rated themselves as having more energy that officers who listened to office noise (Jahncke et al. 2011).

\section{References}

Barek J, Cabalková D, Fischer J, Navrátil T, Pecková K, Yosypchuk B (2009) Voltammetric determination of the herbicide Bifenox in drinking and river water using a silver solid amalgam electrode. Environ Chem Lett 9(1):83-86. https://doi.org/10.1007/ s10311-009-0250-x

Barra R, Quiroz R, Saez K, Araneda A, Urrutia R, Popp P (2008) Sources of polycyclic aromatic hydrocarbons (PAHs) in sediments of the Biobio river in south central Chile. Environ Chem Lett 7(2):133-139. https://doi.org/10.1007/s10311-008-0148-z 
Bonesi M, Loizzo MR, Menichini F, Tundis R (2018) Flavonoids in Treating Psoriasis. 281-294. https://doi.org/10.1016/b978-0-12805417-8.00023-8

Dai H, Han J, Lichtfouse E (2021) Smarter cures to combat COVID-19 and future pathogens: a review. Environ Chem Lett 19(4):27592771. https://doi.org/10.1007/s10311-021-01224-9

Doi H, Katano I, Negishi JN, Sanada S, Kayaba Y (2013) Effects of biodiversity, habitat structure, and water quality on recreational use of rivers. Ecosphere 4 (8):art102. doi:https://doi.org/10.1890/ es12-00305.1

Dsikowitzky L, Schäfer L, Dwiyitno AF, Irianto HE, Schwarzbauer J (2017) Evidence of massive river pollution in the tropical megacity Jakarta as indicated by faecal steroid occurrence and the seasonal flushing out into the coastal ecosystem. Environ Chem Lett 15(4):703-708. https://doi.org/10.1007/s10311-017-0641-3

Duhau I (2007) Les baignades en rivière d'Île-de-France: Des premiers aménagements à la piscine parisienne Joséphine Baker. Livraisons d'histoire de l'architecture 14:9-38. https://www.persee.fr/ doc/lha_1627-4970_2007_num_14_1_1083

Duman M, DurgunOzan Y, AksoyDerya Y, TimurTaşhan S (2020) The effect of relaxation exercises training on pregnancy-related anxiety after perinatal loss: a pilot randomized control trialit. Explore. https://doi.org/10.1016/j.explore.2020.11.002

Fabbri J, Maggiore MA, Pensel PE, Albani CM, Denegri GM, Elissondo MC (2018) Could beta-myrcene be an alternative to albendazole for the treatment of experimental cystic echinococcosis? Acta Trop 187:5-12. https://doi.org/10.1016/j.actatropica.2018. 07.013

Feng R, Wang Q, Huang C-c, Liang J, Luo K, Fan J-r, Zheng H-j (2018) Ethylene, xylene, toluene and hexane are major contributors of atmospheric ozone in Hangzhou, China, prior to the 2022 Asian games. Environ Chem Lett 17(2):1151-1160. https://doi. org/10.1007/s10311-018-00846-w

Gecheva G, Yurukova L (2013) Water pollutant monitoring with aquatic bryophytes: a review. Environ Chem Lett 12(1):49-61. https://doi.org/10.1007/s10311-013-0429-z

Gu G, Frasson C, 2017 Virtual Sophrologist: A Virtual Reality Neurofeedback Relaxation Training System 10512, 176-185 https:// doi.org/10.1007/978-3-319-67615-9_16

He S, Shao W, Han J (2021) Have artificial lighting and noise pollution caused zoonosis and the COVID-19 pandemic? A review. Environ Chem Lett 19(6):4021-4030. https://doi.org/10.1007/ s10311-021-01291-y

Heim S, Schwarzbauer J, Kronimus A, Littke R, Hembrock-Heger A (2003) Organic pollutants in riparian wetlands of the Lippe river (Germany). Environ Chem Lett 1(3):169-173. https://doi.org/10. 1007/s10311-003-0040-9

Jahncke H, Hygge S, Halin N, Green AM, Dimberg K (2011) Openplan office noise: cognitive performance and restoration. J Environ Psychol 31(4):373-382. https://doi.org/10.1016/j.jenvp.2011.07. 002

Jhunjhunwala B, Waghralkar R (2021) Observational case studies of the effect of phage laden Ganga water on psoriasis. IP Indian J Clin Exp Dermatol 7(3):186-190. https://doi.org/10.18231/j.ijced. 2021.037

Jin K-S, Jun M-R, Park M-J, Ok S, Jeong J-H, Kang H-S, Jo W-K, Lim H-J, Jeong W-S (2008) Promises and risks of unsaturated volatile organic compounds: limonene, pinene, and isoprene. Food Sci Biotechnol 17(3):447-456

Juang DE, Yuan CS, Hsueh SC, Chiou LJ (2008) Distribution of volatile organic compounds around a polluted river. Int J Environ Sci Technol 6(1):91-104. https://doi.org/10.1007/bf03326063

Khalaj F, Rivas-Ubach A, Anderton CR, China S, Mooney K, Faiola CL (2021) Acyclic terpenes reduce secondary organic aerosol formation from emissions of a riparian shrub. ACS Earth Space
Chem 5(5):1242-1253. https://doi.org/10.1021/acsearthspacech em.0c00300

Khan AH, Tirth V, Fawzy M, Mahmoud AED, Khan NA, Ahmed S, Ali SS, Akram M, Hameed L, Islam S, Das G, Roy S, Dehghani MH (2021) COVID-19 transmission, vulnerability, persistence and nanotherapy: a review. Environ Chem Lett 19(4):2773-2787. https://doi.org/10.1007/s10311-021-01229-4

Kistemann T, Schmidt A, Flemming H-C (2016) Post-industrial river water quality-fit for bathing again? Int J Hyg Environ Health 219(7):629-642. https://doi.org/10.1016/j.ijheh.2016.07.007

Li Q (2009) Effect of forest bathing trips on human immune function. Environ Health Prevent Med 15(1):9-17. https://doi.org/10.1007/ s12199-008-0068-3

Lo H-Y, Li C-C, Cheng H-M, Liu IC, Ho T-Y, Hsiang C-Y (2019) Ferulic acid altered IL-17A/IL-17RA interaction and protected against imiquimod-induced psoriasis-like skin injury in mice. Food Chem Toxicol 129:365-375. https://doi.org/10.1016/j.fct.2019.04.060

Macintyre (2021) BEN MACINTYRE 'The history of wild swimming' Friday September 17 2021, The Times. https://www.thetimes.co. uk/article/the-history-of-wild-swimming-kcm6svvwr

Mao G-X, Cao Y-B, Lan X-G, He Z-H, Chen Z-M, Wang Y-Z, Hu X-L, Lv Y-D, Wang G-F, Yan J (2012) Therapeutic effect of forest bathing on human hypertension in the elderly. J Cardiol 60(6):495-502

Nanusha MY, Krauss M, Brack W (2020) Non-target screening for detecting the occurrence of plant metabolites in river waters. Environ Sci Eur. https://doi.org/10.1186/s12302-020-00415-5

Park C-H, Min S-Y, Yu H-W, Kim K, Kim S, Lee H-J, Kim J-H, Park Y-J (2020) Effects of apigenin on RBL-2H3, RAW264.7, and HaCaT cells: anti-allergic, Anti-inflammatory, and skin-protective activities. Int J of Molecular Sci 21(13):4620. https://doi.org/10. 3390/ijms21134620

Robinson JM, Breed MF (2019) Green prescriptions and their co-benefits: integrative strategies for public and environmental health. Challenges 10(1):9

Roviello V, Roviello GN (2021a) Less COVID-19 deaths in southern and insular Italy explained by forest bathing, Mediterranean environment, and antiviral plant volatile organic compounds. Environ Chem Lett. https://doi.org/10.1007/s10311-021-01309-5

Roviello V, Roviello GN (2021b) Lower COVID-19 mortality in Italian forested areas suggests immunoprotection by Mediterranean plants. Environ Chem Lett 19(1):699-710

Roviello V, Gilhen-Baker M, Vicidomini C, Roviello GN (2021) Forest-bathing and physical activity as weapons against COVID19: a review. Environ Chem Lett. https://doi.org/10.1007/ s10311-021-01321-9

Roviello V, Roviello G (2019) Recent Records of the Eurasian Otter (Lutra Lutra) in the Mercure-Lao River Valley, South Italy.

Sadoff CW, Grey D (2002) Beyond the river: the benefits of cooperation on international rivers. Water Policy 4(5):389-403

Samelak I, Balaban M, Antić M, Šolević Knudsen T, Jovančićević B (2019) Geochromatographic migration of oil pollution from a heating plant to river sediments. Environ Chem Lett 18(2):459466. https://doi.org/10.1007/s10311-019-00937-2

Shu H, Chen H, Wang X, Hu Y, Yun Y, Zhong Q, Chen W, Chen W (2019) Antimicrobial activity and proposed action mechanism of 3 -carene against brochothrix thermosphacta and pseudomonas fluorescens. Molecules 24(18):3246. https://doi.org/10.3390/ molecules 24183246

Stinco G, Trevisan G, Piccirillo F, Pezzetta S, Errichetti E, di Meo N, Valent F, Patrone P (2014) Pruritus in chronic plaque psoriasis: A questionnaire-based study on 230 Italian patients. Acta Dermatovenerologica Croatica 22(2):122

Terasaki M, Takemura Y, Makino M (2012) Paraben-chlorinated derivatives in river waters. Environ Chem Lett 10(4):401-406. https:// doi.org/10.1007/s10311-012-0367-1 
Torsekar R, Gautam M (2017) Topical therapies in psoriasis. Indian Dermatol Online J 8(4):235. https://doi.org/10.4103/2229-5178. 209622

Ufnalska S, Lichtfouse E (2021) Unanswered issues related to the COVID-19 pandemic. Environ Chem Lett 19(5):3523-3524. https://doi.org/10.1007/s10311-021-01249-0

Wang Z, Qin Y, Li W, Yang W, Meng Q, Yang J (2019) Microplastic contamination in freshwater: first observation in Lake Ulansuhai, yellow river Basin. China Environmental Chemistry Letters 17(4):1821-1830. https://doi.org/10.1007/s10311-019-00888-8

Wei J-a, Han L, Lu C-j, Zhao R-z, Sun J, Lu Y, Lin H-j (2016) Formula PSORI-CM01 eliminates psoriasis by inhibiting the expression of keratinocyte cyclin B2. BMC Complement Altern Med. https:// doi.org/10.1186/s12906-016-1234-6

Wu Y, Wang P, Yu S, Wang L, Li P, Li Z, Mehmood K, Liu W, Wu J, Lichtfouse E, Rosenfeld D, Seinfeld JH (2018) Residential emissions predicted as a major source of fine particulate matter in winter over the Yangtze River Delta. China Environ Chem Lett 16(3):1117-1127. https://doi.org/10.1007/s10311-018-0735-6

Zhang Y, Xia Q, Li Y, He Z, Li Z, Guo T, Wu Z, Feng N (2019) CD44 Assists the topical anti-psoriatic efficacy of curcumin-loaded hyaluronan-modified ethosomes: a new strategy for clustering drug in inflammatory skin. Theranostics 9(1):48-64. https://doi.org/ 10.7150/thno.29715

Publisher's Note Springer Nature remains neutral with regard to jurisdictional claims in published maps and institutional affiliations. 